\title{
EVALUASI PELAKSANAAN PEMENUHAN KEWAJIBAN PAJAK ORANG PRIBADI TERTENTU PADA KANTOR PELAYANAN PAJAK PRATAMA PONDOK AREN
}

Ambarwati

Institut Ilmu Sosial dan Manajemen STIAMI

ambaryusuf26@gmail.com

\begin{tabular}{|c|c|}
\hline ARTIKEL INFO & ABSTRACT \\
\hline $\begin{array}{l}\text { Keywords: } \\
\text { awareness, knowledge of } \\
\text { taxation, attitude of the } \\
\text { taxpayer and taxpayer } \\
\text { compliance. }\end{array}$ & $\begin{array}{l}\text { Self assessment system of Indonesian taxation demands high level of } \\
\text { taxpayers' awareness and compliance in fulfilling tax liabilities in order to } \\
\text { increase state revenue from taxation sector. The level of compliance could be } \\
\text { increased through providing better service quality by the taxation office, } \\
\text { which includes safety, comfort, and quick services, as well as law } \\
\text { enforcement. This study is to determine whether there is influence } \\
\text { understanding of tax laws, the tax rate and the principle of fairness on tax } \\
\text { compliance, Micro, Small and Medium Enterprises after the enactment of } \\
\text { Government Regulation No. } 46 \text { Year } 2013 \text {. } \\
\text { Information and Communication Technology Utilization is influential } \\
\text { to or delivered an impact on the increase of taxpayers' obedience. this study } \\
\text { uses descriptive types of qualitative research. Data has obtained by the } \\
\text { interview for extensification and counseling, practitioners and tax academy } \\
\text { as well as Business Development Service (BDS) participants in Kantor } \\
\text { Pelayanan Pajak Pratama Pondok Aren. The result of this research indicates } \\
\text { that the taxpayers' awareness does not significantly influence on taxpayers } \\
\text { compliance. Knowledge of taxation significantly affects on taxpayers, } \\
\text { compliance. Taxpayers, attitudes significantly affect on taxpayers, } \\
\text { compliance. }\end{array}$ \\
\hline
\end{tabular}

\section{LATAR BELAKANG}

Sebagai sumber dana terbesar dalam pelaksanaan Pemerintah dan pembangunan maka peranan penerimaan pajak dari tahun ke tahun akan semakin meningkat dalam mendukung pembangunan nasional, hal ini tercermin dengan meningkatnya rencana penerimaan pajak. Adanya pajak diharapkan akan meningkatkan kesejahteraan hidup semua masyarakat Dalam melakukan pemungutan pajak di Indonesia, salah satu prinsip yang dianut adalah Good Corporate Governance (GCG) adalah tranparansi, yang berarti setiap transaksi yang terjadi harus didokumentasikan dalam laporan keuangan yang mengacu pada standar akuntansi yang berlaku secara umum serta dicermati apakah mengandung unsur pajak. Sedangkan dalam melakukan pemungutan pajak di Indonesia menganut tiga sistem, Official Assesment System, Self Assessment System dan Witholding System, masing-masing sistem memiliki keistimewaan. Akan tetapi yang memiliki peranan sangat penting dan lebih dominan adalah Self Assesment System dikarenakan penerapannya pada sistem pemungutan Pajak Penghasilan. Sistem self assessment merupakan suatu kepercayaan yang diberikan penuh kepada wajib pajak untuk menghitung, menyetor, serta melaporkan seluruh kewajiban pajaknya.

Sering kali terjadi kesalahan dalam pengisian Nomor pokok wajib pajak (NPWP) yang seharusnya diisikan dalam SPT Tahunan adalah NPWP wajib pajak sendiri yang terdapat pada kartu NPWP wajib pajak masing-masing. Jika wajib pajak menggunakan sistem online maka kendala yang sering terjadi adalah tidak menguasai sistem dengan baik dan tersedianya sistem internet yang baik. Pelaporan SPT bagi wajib pajak atau lembaga yang telah memiliki NPWP. Kendala yang sering dihadapi oleh wajib pajak dalam menyusun/ mengisi SPT adalah kurang pahamnya Wajib Pajak dalam pengisiannya dan hal yang paling mendasar adalah bentuk formulir yang sering berubah-ubah.

Fiskus berperan dalam melakukan penelitian atas kelengkapan dan kebenaran pelaporan serta melakukan pemeriksaan untuk mengetahui kebenaran materi dalam laporan wajib pajak, atau dalam hal ini Surat Pemberitahuan, sistem ini digunakan oleh wajib pajak karena mereka diwajibkan untuk 
mengisi SPT, yang berarti wajib pajak tersebut wajib menghitung menyetor dan melaporkan pajak penghasilan terutangnya sendiri tanpa melalui pihak ketiga atau fiskus. Sistem pemungutan pajak ini mempunyai arti bahwa pemberian kepercayaan sepenuhnya pada Wajib Pajak untuk menentukan penetapan besarnya pajak yang terutang sendiri, dan kemudian melaporkan pembayaran pajak dan perhitungan pajak secara teratur jumlah pajak terutang dan yang telah dibayar sebagaimana ditentukan dalam peraturan perundang-undang perpajakan. Dalam pelaksanaannya sistem ini dapat meningkatkan penerimaan karena dilakukan sesuai dengan sistem yang telah diterapkan. Penggunaan sistem ini untuk memberi kepercayaan kepada Wajib Pajak untuk memenuhi dan melaksanakan sendiri kewajiban dan hak perpajakanya.

Demikian pula dengan sistem pelaporan yang dilakukan di suatu badan maupun orang pribadi, yang sering terjadi di lapangan adalah ketidak pahaman pemilik perusahaan maupun orang pribadi melaporkan SPT setiap tahun, Kekeliruan terjadi seperti Wajib Pajak kurang teliti dalam menghitung jumlah pajak penghasilan yang harus dibayar atau PPh kurang Bayar.

\section{KAJIAN TEORI}

\section{Evaluasi}

Hadi (2011:13) mendefinisikan evaluasi sebagai "proses mengumpulkan informasi mengenai suatu objek, menilai suatu objek, dan membandingkannya dengan kriteria, standar dan indikator", menurut pendapat Charles O. Jones dalam Aprilia (2009) adalah "evaluation is an activity which can contribute greatly to the understanding and improvement of policy development and implementation".

Wirawan (2012:7) evaluasi adalah: "Riset untuk mengumpulkan, menganalisis, dan menyajikan informasi yang bermanfaat mengenai objek evaluasi, selanjutnya menilainya dan membandingkannya dengan indikator evaluasi dan hasilnya dipergunakan untuk mengambil keputusan mengenai objek evaluasi tersebut.

Menurut Ernest R. Alexander dalam Aminudin (2007), metode evaluasi dapat diklasifikasikan menjadi lima yaitu :

1. Before and after comparisons, metode ini mengkaji suatu obyek penelitian dengan membandingkan antara kondisi sebelum dan kondisi sesudahnya.

2. Actual versus planned performance comparisons, metode ini mengkaji suatu obyek penelitian dengan membandingkan kondisi yang ada (actual) dengan ketetapan perencanaan yang ada (planned)

3. Experintal (controlled) model, metode yang mengkaji suatu obyek penelitian dengan melakukan percobaan yang terkendali untuk mengetahui kondisi yang diteliti.

4. Quasi experimental models, merupakan metode yang mengkaji suatu obyek penelitian dengan melakukan percobaan tanpa melakukan pengontrolan/pengendalian terhadap kondisi yang diteliti.

5. Cost oriented models, metode ini mengkaji suatu obyek penelitian yang hanya berdasarkan pada penilaian biaya terhadap suatu rencana.

\section{Pelaksanaan}

Dalam merumuskan proses pelaksanaan (Implementasi) sebagai berikut "implementasi (Pelaksanaan) adalah pelaksanaan keputusan kebijakan dasar, biasanya dalam bentuk undang-undang, namun dapat pula berbentuk perintah atau keputusan badan eksekutif yang penting ataupun keputusan peradilan Mazmanian dan Sebatier yang dikutip dalam Solihin Abdul Wahab.

Beberapa hal mempengaruhi berhasilnya suatu pelaksanaan yaitu :

1. Komunikasi, merupakan suatu program yang dapat dilaksanakan dengan baik apabila jelas bagi para pelaksana. Hal ini menyangkut proses penyampaian informasi, kejelasan informasi dan konsistensi informasi yang disampaikan.

2. Resources (sumber daya), dalam hal ini meliputi empat komponen yaitu terpenuhinya jumlah staf dan kualitas mutu, informasi yang diperlukan guna pengambilan keputusan atau kewenangan yang cukup guna melaksanakan tugas sebagai tanggung jawab dan fasilitas yang dibutuhkan dalam pelaksanaan. 
3. Disposisi, sikap dan komitmen dari pada pelaksanaan terhadap program khususnya dari mereka yang menjadi implementasi program khususnya dari mereka yang menjadi implementer program.

4. Struktur birokrasi, yaitu SOP (Standar Operating Procedures) yang mengatur tata aliran dalam pelaksanaan program. Jika hal ini tidak sulit dalam mencapai hasil yang memuaskan, karena penyelesaian masalah- masalah akan memerlukan penangan dan penyelesaian khusus tanpa pola yang baku.

\section{Kewajiban}

Kewajiban adalah pengorbanan manfaat ekonomik masa datang yang cukup pasti yang timbul dari keharusan sekarang suatu kesatuan usaha untuk mentransfer asset atau menyediakan /menyerahkan jasa kepada kesatuan lain di masa datang sebagai akibat transaksi ataukejadian masa lalu .) Dengan makna yang sama, IASC mendefinisi kewajiban sebagai berikut:

"A liability is a present obligation of the enterprise a rising from past events, the settlement of which is expected to result in an outflow from the enterprise resources embodying economic benefit".

\section{Kebijakan}

Ide kebijakan melibatkan perilaku yang memiliki maksud dan tujuan merupakan bagian yang penting dari definisi kebijakan, karena bagaimanapun kebijakan harus menunjukan apa yang sesungguhnya dikerjakan daripada apa yang diusulkan dalam beberapa kegiatan pada suatu masalah.

Carl J Federick sebagaimana dikutip Leo Agustino (2008:7) mendefinisikan kebijakan sebagai serangkaian tindakan/kegiatan yang diusulkan seseorang, kelompok atau pemerintah dalam suatu lingkungan tertentu dimana terdapat hambatan-hambatan (kesulitan-kesulitan) dan kesempatankesempatan terhadap pelaksanaan usulan kebijaksanaan tersebut dalam rangka mencapai tujuan tertentu.

\section{Model Penelitian}

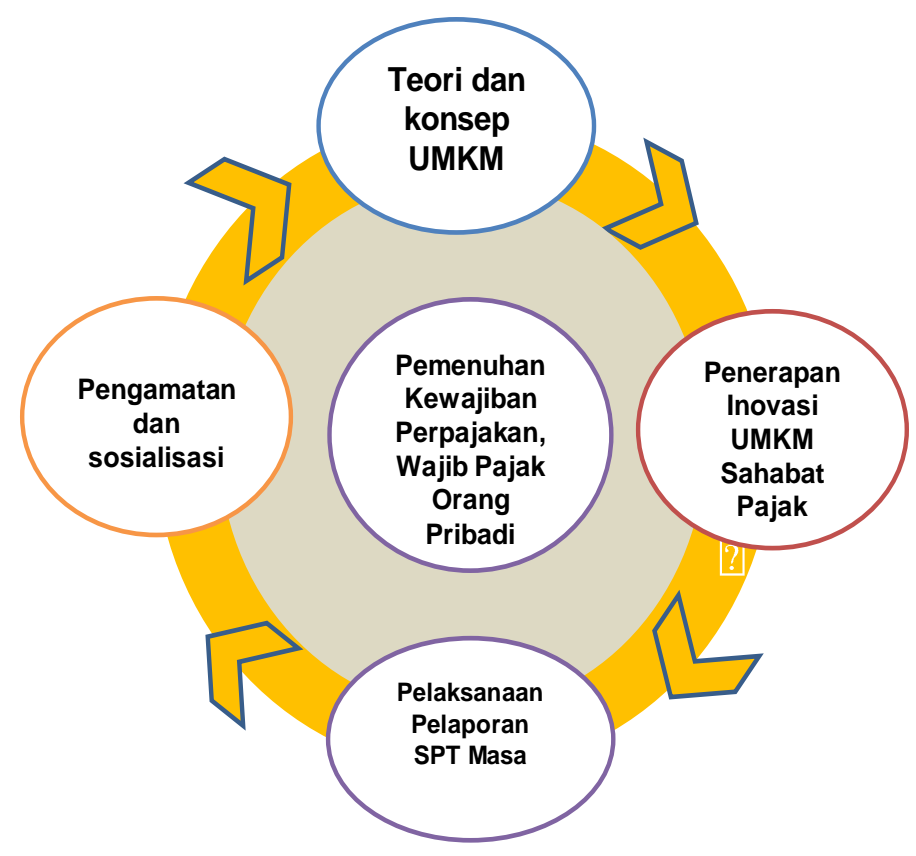

Gambar 1. 


\section{METODE PENELITIAN}

Paradigma Penelitian yang dilakukan dengan adanya salah satu fenomena administrasi yang terjadi sangat dipengaruhi dengan kualitas Pelayanan dari setiap Kantor Pelayanan Pajak, Sehingga Paradigma penelitan akan dilakukan lebih kepada tingkat pelayanan yang ada di Kantor Pelayanan Pajak dan kualitas pengetahuan yang dimiliki setiap petugas untuk dapat memberikan penjelasan atau sosialisasi yang lebih kepada wajib pajak.

Fokus memberikan batasan dalam studi dan batasan dalam pengumpulan data, sehingga dengan adanya Batasan tersebut peneliti akan fokus dalam memahami masalah-masalah yang menjadi tujuan penelitian. Dalam sebuah penelitian yang bersifat kualitatif karena fokus penelitian memegang peranan yang penting dalam memandu serta mengarahkan jalannya suatu penelitian.

Penelitian ini, menggunakan Metode Analisis Deskriptif yaitu metode yang membandingkan antara data maupun informasi yang diperoleh dari penelitian langsung pada kantor pelayanan pajak dengan pengetahuan atau landasan teori yang diperoleh dari literatur yang tersedia yang berkenaan dengan masalah yang diteliti.

Lokasi penelitian dilaksanakan pada Kantor Pelayanan Pajak (KPP) Pratama Pondok Aren. Alamat : Gedung L Kampus STAN, Jalan Bintaro Utama Sektor V, Bintaro, Pondok Aren, Jurang Manggu Timur, Pd. Aren, Kota Tangerang Selatan, Banten 15222 Banten.

\section{HASIL PENENLITIAN DAN PEMBAHASAN}

Modernisasi perpajakan dilakukan berdasarkan OrganisasI dan Tata kerja Instansi vertical Direktorat Jenderal Pajak, kepada Peraturan Menteri Keuangan. Berikut wilayah kerja KPP (Kantor Pelayanan Pajak) Pratama Pondok Aren berdasarkan Peraturan Menteri Keuangan Nomor 206.2/PMK.01/2014 Tanggal 17 Oktober 2014 :

1. Kecamatan Pamulang

2. Kecamatan Ciputat

3. Kecamatan Ciputat Timur

4. Kecamatan Pondok Aren

Hasil penelitian merupakan hasil yang peneliti dapatkan selama melakukan penelitian pada Kantor Pelayanan Pajak Pratama Pondok Aren Tangerang Selatan. Setelah menjabarkan hal-hal yang melatar belakangi penelitian, teori-teori yang telah mengukuhkan penelitian, maupun metode penelitian yang digunakan, maka pada bab selanjutnya akan dipaparkan tentang hasil dari penelitian.

Tabel 1. Data Jumlah Penduduk serta Persentase Penduduk yang memiliki NPWP

\begin{tabular}{|l|c|c|c|}
\hline \multicolumn{1}{|c|}{ Kecamatan } & Jumlah Penduduk & $\begin{array}{c}\text { Jumlah Wajib Pajak } \\
\text { Orang Pribadi }\end{array}$ & $\begin{array}{c}\text { Penduduk ber NPWP } \\
(\%)\end{array}$ \\
\hline Kec.Pamulang & 314.931 & 82.934 & $26 \%$ \\
\hline Kec. Ciputat & 212.824 & 50.293 & $25 \%$ \\
\hline Kec. Ciputat Timur & 193.484 & 47.788 & $23 \%$ \\
\hline Kec. Pondok Aren & 341.416 & 79.924 & \\
\hline Jumlah & 1.062 .655 & 260.939 & \\
\hline
\end{tabular}

Sumber : KPP Pratama Pondok Aren 


\section{JUMLAHWAJIBPAJAK PADAKPPPRATAMAPONDOKAREN}

Tahun 2015 s/d 2017

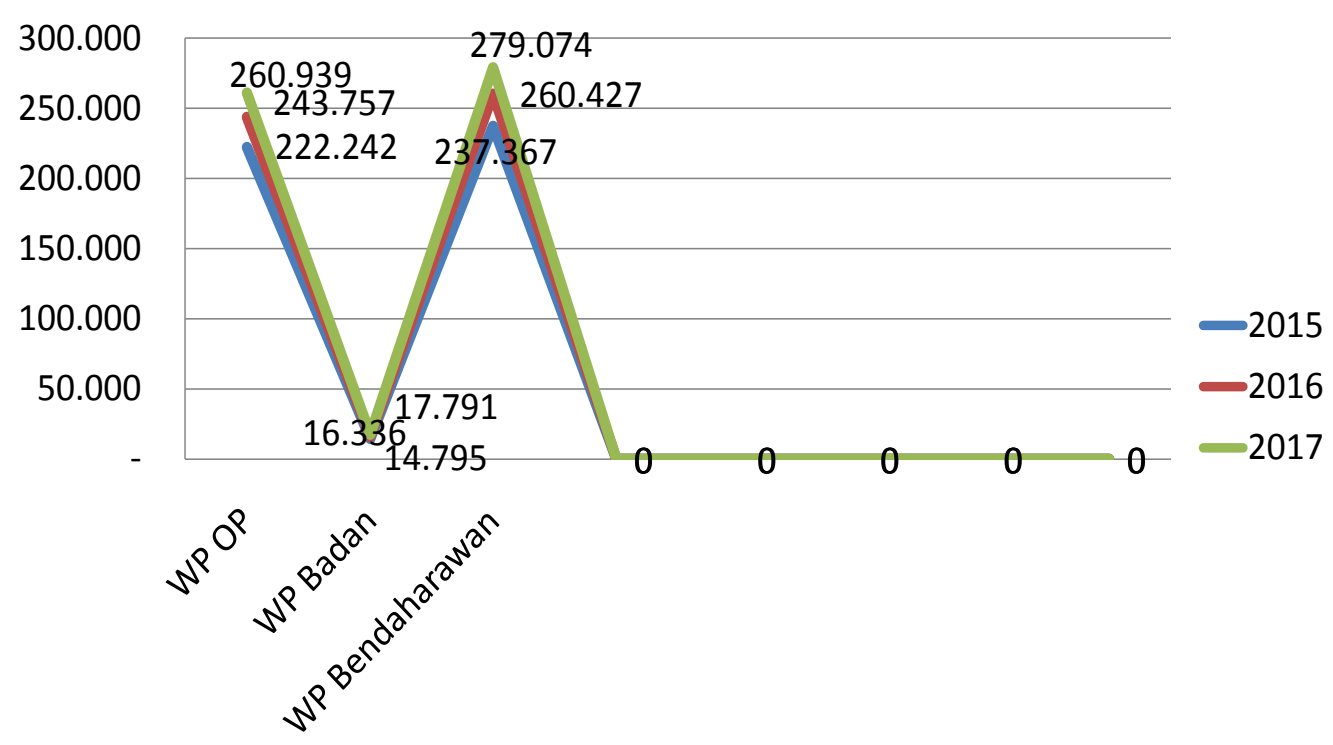

Sumber : Kantor Pelayanan Pajak Pratama Pondok Aren

Dari grafik tersebut diatas terlihat jumlah Wajib Pajak Bendaharwan lebih meningkat dibandingkan dengan Wajib Pajak Orang Pribadi secara keseluruhan termasuk Karyawan dan Non Karyawan, namun untuk meningkatkan kepatuhan pajak Orang Pribadi , masih dapat dilakukan dengan Inovasi yang saat ini dilakukan oleh Kantor Pelayanan Pajak Pratama Pondok Aren.

\section{Strategi Analisis Data Kantor Pelayanan Pajak Pratama Pondok Aren.}

Strategi analisis data yang digunakan dengan pendekatan kualitatif. antara satu dengan strategi lain strategi saling memperkuat. Strategi yang di tempuh guna meningkatkan dan menjaga kepatuhan Wajib Pajak Orang Pribadi yang telah dilaksanakan KPP Pratama Pondok Aren diantaranya adalah meningkatkan Program Penyuluhan kepada masyarakat, dengan pelayanan langsung kepada masyarakat yaitu pelayanan yang dilaksankan melalui kontak langsung dengan masyarakat yang manfaatnya dirasakan langsung.

Penerapan teknologi informasi akan membantu pegawai dalam melakukan pekerjaannya dengan cara mengurangi keterbatasan yang dimilikinya. Memanfaatkan platform social media ( Whatsapp dan telegram) yaitu dengan cara membuat suatu grup yang berisikan anggota komunitas UMKM Sahabat Pajak (USP) diaplikasi social media. Proses penyampaian informasi trik bisnis dan himbauan patuh pajak dapat disampaikan dengan lebih mudah, cepat dan hemat. Keterikatan antara wajib pajak dan fiskus terjalin pun dapat terjalin lebih baik. 
JUMLAHWAJIBPAJAK ORANG PRIBADIKPP PRATAMAPONDOKAREN

Tahun 2015 s/d 2017

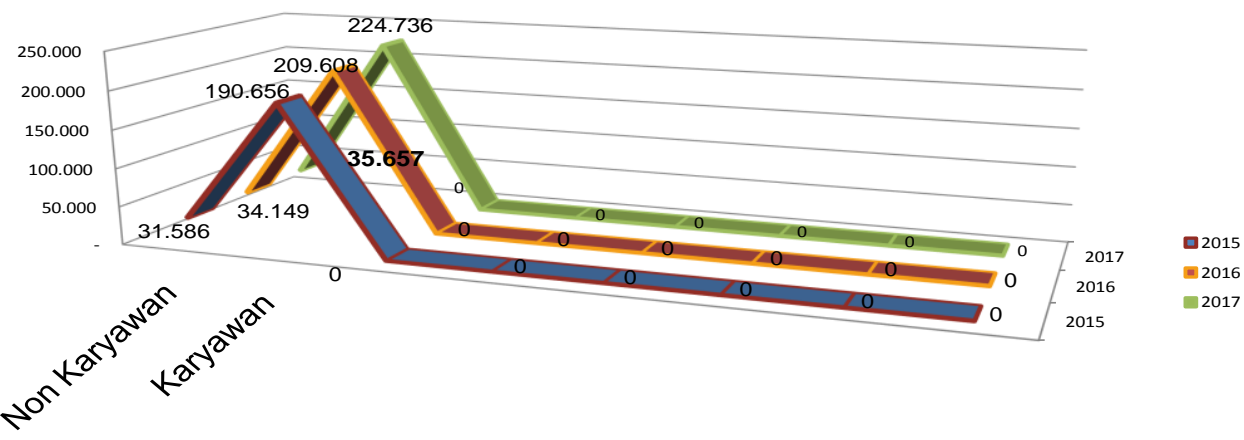

Sumber : Kantor Pelayanan Pajak Pratama Pondok Aren

Dari grafik tersebut diatas terlihat bahwa Wajib Pajak Orang Probadi non Karyawan semakin meningkat dari tahin 2015 samai dengan 2017, ini menandakan bahwa kesadaran terhadap kewajiban terhadap perpajakan ada peningkatan meningkatan walaupun jumlah dibandingkan dengan Karyawan yang secara langsung mempunyai kewajiban dalam perpajakannya.

\section{JUMLAHWAJBPAJAKORANG PRIBADISPT LAPORTEPATWAKTU KPPPRATAMAPONDOKAREN}

Tahun 2015 s/d 2017

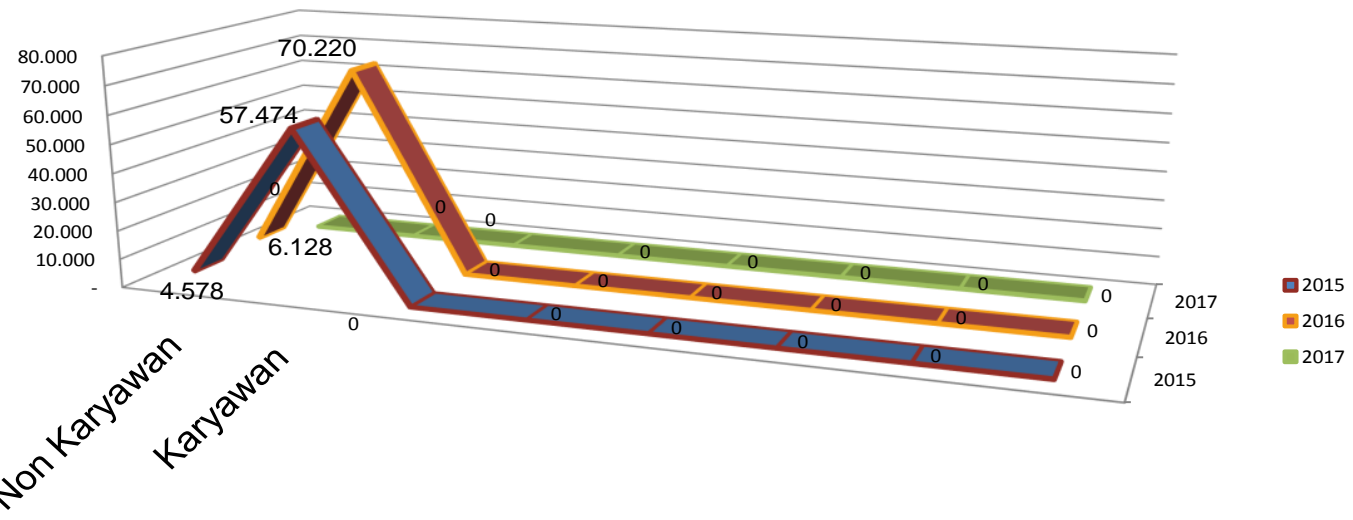

Sumber : Kantor Pelayanan Pajak Pratama Pondok Aren 
Data data yang didapatkan dari Kantor Pelayanan Pajak Pratama Pondok Aren, dalam grafik terlihat bahwa pelaporan SPT yang dilakukan oleh Wajib Pajak Orang Pribadi non Karyawan untuk tepat waktu sangat tidak menunjukkan peningkatan yang baik dari jumlah Wajib pajak Orang Pribadi, demikian pula dengan tingkat kepatuhan yang dilakukan oleh Karyawan dalam pelaporan SPT untuk tepat waktu sangat minim dibandingkan dengan jumlah Wajib Pajak Orang Pribadi yang Karyawan itu sendiri.

Dari grafik-grafik tersebut diatas jelas bahwa harus ada upaya yang dilakukan oleh Kantor pelayanan Pajak Pratama Pondok Aren untuk meningkatkan kepatuhan Wajib pajak Orang Pribadi. Upaya yang dilakuakn untuk meningkatkan kepatuhan wajib pajak, salah satu caranya adalah Salah memberikan pelayanan yang baik kepada wajib pajak. Harapannya dengan meningkatannya kualitas dan kuantitas pelayanan dapat meningkatkan kepuasan kepada wajib pajak sebagai pelanggan sehingga meningkatkan kepatuhan dalam bidang perpajakan.

\section{Aspek Kegiatan Kantor Pelayanan Pajak Pratama Pondok Aren.}

Pembinaan Wajib Pajak UKM melalui program BDS ( Business Development Service) merupakan kegiatan pelatihan dan pembinaan terhadap para pelaku UKM yang dilakukan dengan memberikan materi yang berisi cara-cara yang mendorong perkembangan usaha para pelaku UKM dan materi terkait perpajakan untuk meningkatkan kepatuhan perpajakan, selain sebagai bentuk pelayanan terhadap UMKM, program Business Development Service merupakan salah satu strategi pendekatan dan penyuluhan untuk memperkenalkan pajak terhadap pelaku UMKM agar mereka peduli pajak dan pada akhirnya dapat memunculkan kepatuhan sekarelawan (Voluntary Compliance). Dasar dari program Bisnis Development Service ( BDS ) adalah kegiatan dilakukan sesuai dengan Surat Durektur P2 Humas Nomor S-971/PJ.09/2014 tanggal 19 Desember 2014 perihal Tema Kegiatan Penyuluhan Perpajakan tahun 2015.

Bentuk kegiatan BDS yang telah telah dilakukan meliputi pelaksanaan pelatihan Bisnis, Workshop dan Seminar tentang pembukuan sederhana via aplikasi, pemasaran Online Via FacebookInstaGram, Branding, Bisnis Diagnostic, pengadaan bazaar produk-produk UMKM serta pelatihan kelas pajak. berdasarkan data Produk Domestik Bruto (PDB) dari kementerian Koperasi dan UMKM berdasarkan data per Desember 2015 jumlah anggota koperasi yang menyumbangkan kontribusi terhadap Pruduk Domestik Bruto sebanyak 20.541.513 orang dan jumlah UMKM tercatat sebesar 60.698.747 unit. Kontribusi UMKM (menurut sumber data Kementerian KUKM didasarkan pada Badan Pusat Statistik 2015) : PDB 61,41\%, Tenaga Kerja :96,71 \%, Ekspor Non Migas :15,73 $\%$. Di akhir 2016 rasio wirausaha Indonesia berdasarkan data Badan Pusat Statistik sudah mencapai $3,1 \%$, dari sebelumnya $1,65 \%$.

Berdasarkan hal tersebut diatas maka KPP Pondok Aren melakukan Inovasi untuk mendukung pelaksanaan pembinaan Wajib pajak UMKM dengan pembinaan Wajib Pajak pelaku UMKM melalui Komunitas UMKM Sahabat Pajak ( USP ) maka terjalin pola kerjasama antara sesama instansi terkait yang berkelanjulatan dalam pembinaan Wajib Pajak UMKM dan dapat memberikan dampak positif terhadap instansi yang terkait. Pembentukan komunitas UMKM Sahabat Pajak memiliki dua tujuan utama yaitu mendukung pengembangan usaha dana meningkatkan kepatuhan pajak para pelaku UMKM. Untuk mencapai tujuan, strategis dari program ini adalah pelaksanaan secara bertahap.

Pemangku kepentingan yang terlibat dalam pelaksanaan kegiatan UMKM Sahabat Pajak mencakup:

a. KPP Pratama Pondok Aren :

1. Kepala Kantor Pelayanan Pajak Pratama Pondok Aren.

2. Kepala Seksi Ektensifikasi dan Penyuluhan.

3. Accaount Representative dan Pelaksana Ektensifikasi.

b. PKN STAN

1. Civitas Akademika.

c. Pusdiklat Pajak;

1. Civitas Akademika.

d. Komunitas UMKM Sahabat Pajak (USP) :

1. Pengurus Komunitas UMKM Sahabat Pajak.

2. Anggota Komunitas UMKM Sahabat Pajak. 


\section{Aspek Keberhasilan Inovasi UMKM Sahabat Pajak (USP)}

Program UMKM Sahabat Pajak yang dijalankan oleh KPP Pratama Pondok Aren ini telah berjalan sejak Agustus 2016 dan telah mendapatkan output (keluaran) yang hasilnya dapat dilihat secara langsung dapat terbentuknya komunitas UMKM Sahabat Pajak yang susunan pengurusnya bukan berasal dari petugas pajak, melainkan tokoh UMKM yang menjadi pengurus sekaligus anggota dari komunitas ini. Sehingga para anggota komunitas ini merasa lebih nyaman untuk saling sharing pemahaman tentang bisnis dan pajak.

Keberhasilan program USP ini dapat dilihat dari banyaknya pihak yang semakin memiliki kepercayaan (trust) bahwa program UMKM Sahabat Pajak ini dapat memberikan banyak manfaat bagi banyak pihak, dapat dilihat dari instansi-instansi lain yang ingin bekerja sama dengan memanfaatkan program ini. Contohnya seperti Badan Ekonomi Kreatif yang merencanakan kerja sama dalam program-program kerjanya yang melibatkan komunitas UMKM dan bersedia membantu pembiayaan event di komunitas UMKM Sahabat Pajak. Program ini juga telah menyediakan market place dan katalog produk bagi UMKM yang menjadi anggota dari komunitas ini. Seperti menyediakan website bagi para anggota untuk memasarkan dan menawarkan produk-produk mereka. Dengan demikian, sektor penjualan mereka menjadi lebih luas pasarnya.

\section{Sistem Pemantauan dan Evaluasi Kegiatan.}

Pengawasan, pemantauan, serta evaluasi UMKM Sahabat Pajak dilaksanakan oleh pegawai KPP Pratama Pondok Aren, Civitas Akademika PKN STAN, Pusdiklat Pajak, serta tokoh-tokoh dan pelaku UMKM itu sendiri. Pelaksanaan pengawasan, pemantauan, dan evaluasi dilakukan untuk :

1. Memastikan bahwa semua tindakan yang dilakukan oleh pihak yang berkaitan mengikuti rencana yang telah disusun;

2. Memastikan bahwa sumber dan layanan yang diperuntukkan bagi anggota USP telah mencapai sasaran;

3. Menghasilkan informasi yang dapat membantu memantau segala hasil perubahan akibat dari implementasi program UMKM Sahabat Pajak;

4. Mendapatkan informasi tentang hambatan-hambatan selama program berlangsung;

5. Mendapatkan gambaran setelah dilaksanakannya program.

\section{Kendala utama yang dihadapi dan cara mengatasinya.}

Ketersediaan dana untuk penyelenggaraan program UMKM sahabat Pajak (USP). Kendala tersebut dapat diatasi dengan berbagai cara, diantaranya dengan mengadakan join budget antara KPP Pratama Pondok Aren dan PKN STAN. Begitu juga dalam hal sponsorship, KPP Pratama Pondok Aren juga menjalin kerja sama dengan institusi lain. Tahun ini, direncanakan bekerja sama dengan Badan Ekonomi Kreatif (BEKRAF). Lalu, pendanaan juga dapat diperoleh dari iuran para anggota UMKM Sahabat Pajak (USP) yang digunakan untuk mengadakan kegiatan mandiri seperti kopi darat. Solusi lainnya dengan membentuk divisi usaha di UMKM Sahabat Pajak (USP), keuntungan dari hasil penjualan dari divisi usaha ini akan turut serta membantu pendanaan program.

Kurangnya Sumber Daya Manusia (SDM) yang bersedia menjadi relawan atau Liaison Officer (LO) untuk mengurus program UMKM Sahabat Pajak (USP). Kendala ini dapat diatasi dengan mengadakan rekrutmen terbuka (oprec) untuk mencari para sukarelawan. Relawan dapat berasal dari mahasiswa PKN STAN yang dalam hal ini akan menjadi pihak Liaison Officer (LO) atau Account Representative (AR) Junior. Lalu, para pelaku UMKM yang telah menjadi mitra USP dan merasakan manfaatnya biasanya bersedia menjadi sukarelawan. Agar pelaku UMKM lainnya berminat untuk bergabung dengan program ini maka perlu dijalin silaturahmi secara berkala antara pihak KPP Pratama Pondok Aren, Civitas Akademika PKN STAN, Pusdiklat Pajak, dan para tokoh UMKM tersebut. Silaturahmi bisa berbentuk acara kopi darat (kopdar) maupun pertemuan pada saat menyelenggarakan event-event tertentu yang berkaitan dengan UMKM.

Sarana dan Prasarana, untuk pelaksanaan berbagai kegiatan, seperti pelatihan, workshop, bazaar, dan pertemuan. KPP bekerjasama dengan PKN STAN, terutama terkait dengan kegiatan yang membutuhkan kepasitas ruangan yang bisa menampung banyak orang. 
Teknologi Informasi merupakan sumber daya yang memegang peran penting. Dengan memanfaatkan koneksi internet, piranti teknologi, berbagi aplikasi, dan social media sangat membantu proses koordinasi menjadi lebih mudah dan berbagai proram kerja berjalan lebih efektif dan efisien.

\section{Perbedaan sebelum dan sesudah inovasi}

Pada saat sebelum inovasi dilakukan, tingkat kehadiran para pelaku UMKM dalam kegiatan penyuluhan pajak yang dilaksanakan oleh KPP Pratama Pondok Aren termasuk kategori sangat rendah. Kemudian ketika inovasi ini dilakukan, ternyata tingkat partisipasi para pelaku UMKM untuk mengikuti kegiatan penyuluhan pajak menjadi drastis peningkatannya. Hal ini dapat dilihat pada saat KPP mengadakan penyuluhan tentang perpajakan sebelum melaksanakan kegiatan ini, jumlah partisipan yang hadir hanya sekitar 5 - 10 orang. Setelah dilakukan kegiatan ini, jumlah partisipan pada penyuluhan yang dilakukan KPP, jumlahnnya meningkat drastis dan bahkan melebihi kuota.

Perbedaan yang kedua adalah dari sisi jumlah pembayar pajak. Sebelumnya, jumlah pembayar pajak hanya sekitar 4\% dari jumlah keseluruhan pelaku UMKM yang tergabung KPP Pratama Pondok Aren. Namun, setelah dilakukan inovasi, jumlah pembayar pajak meningkat drastis menjadi sekitar kurang lebih 90\% dari keseluruhan pelaku UMKM yang tergabung di USP. Hal ini disebabkan setelah dilakukannya program ini, para pelaku UMKM tergerak hatinya untuk melakukan melaksanakan pembayaran pajak. Ini disebabkan karena kepercayaan mereka terhadap pajak meningkat sekaligus menghilangkan paradigma negatif mengenai pajak selama ini. Paradigma tersebut secara perlahan telah tergantikan dengan pemikiran positif tentang pajak melalui komunitas UMKM Sahabat Pajak (USP) itu sendiri. Akibatnya, jumlah partisipasi pelaku UMKM dalam melaksanakan pembayaran pajak dapat meningkat dengan secara signifikan.

Perbedaan yang ketiga adalah omset UMKM. Setelah program ini dilakukan, mayoritas omset para anggota USP cenderung meningkat. Peningkatan omsetnya pun bervariasi. Walaupun ada sebagian kecil dari UMKM yang omsetnya masih stagnan, sebagian besar dari mereka terus berkembang dan omsetnya meningkat setelah mereka mengikuti program UMKM Sahabat Pajak ini. Dengan demikian, jumlah pajak yang mereka bayarkan juga akan turut meningkat yang berimbas pada meningkatnya penerimaan Negara meskipun, jumlahnya tidak sebesar jika dibandingkan dengan setoran pajak dari Wajib Pajak besar non UMKM yang lebih dulu berkembang. Meskipun demikian, dengan omset para UMKM yang terus meningkat diharapkan usaha

mereka terus berkembang dan menjadi pengusaha besar sehingga jumlah setoran pajaknya pun akan semakin meningkat dan akan berkontribusi besar bagi realisasi penerimaan negara terutama dari sektor pajak.

Kemudian yang keempat adalah beban kerja yang ditanggung oleh KPP Pratama Pondok Aren. Sebelumnya, beban kerja untuk melaksanakan suatu kegiatan penyuluhan keseluruhannya dilaksanakan oleh KPP Pratama Pondok Aren. Namun, setelah program ini dilakukan, terjadi sinergi antara KPP Pratama Pondok Aren, PKN STAN, UMKM Sahabat Pajak, dan Pusdiklat Pajak sehingga pada saat diselenggarakan suatu kegiatan, beban pekerjaan tidak lagi hanya dilaksanakan oleh KPP Pratama Pondok Aren, tetapi juga dilaksankan oleh PKN STAN, Pusdiklat Pajak, serta UMKM Sahabat Pajak (USP). Selain itu, KPP juga mendapat kepercayaan dari banyak pihak lain seperti Badan Ekonomi Kreatif (BEKRAF), di mana mereka dapat mendukung dan turut menyelenggrakan kegiatan yang dilaksanakan oleh USP.

Terdapat juga perubahan untuk mahasiswa PKN STAN. Sebelum dilaksanakannya program ini, mahasiswa PKN STAN sulit mendapat gambaran mengenai penerapan ilmu yang dipelajari di kampus dengan realitas dan praktiknya ketika sudah bekerja di Direktorat Jenderal Pajak. Setelah dilaksanakannya program ini, para mahasiswa PKN STAN yang berpartisipasi dalam kegiatan program ini menjadi semakin memahami pengaplikasian ilmu yang diperoleh selama di kampus untuk praktik di lapangan. Selain itu, program ini juga memberikan kesempatan bagi mahasiswa untuk berinteraksi langsung dengan masyarakat, sehingga setelah lulus akan menjadi sebuah bekal pengalaman yang sangat membantu mereka ketika bekerja di Direktorat Jenderal Pajak. 


\section{KESIMPULAN DAN SARAN}

\section{Kesimpulan}

Berdasarkan hasil penelitian dan pembahasan mengenai Evaluasi Plelaksanaan Pemenuhan Kewajiban Pajak Orang Pribadi tertentu pada Kantor Pelayanan Pajak Pratama Pondok Aren, maka dapat ditarik kesimpulan bahwa :

1. Pemahaman peraturan pajak akan memberikan pengaruh positif terhadap kepatuhan wajib pajak orang pribadi dikarenakan semakin wajib pajak mengetahui dan memahami peraturan pajak maka wajib pajak akan semakin sadar akan pentingnya pajak dan paham atas peraturan-peraturan tersebut dapat diterima sehingga wajib pajak patuh terhadap peraturan pajak. Kesadaran responden yang merupakan wajib pajak orang pribadi yang melakukan usaha melalui UMKM masih nampak kurang, hal ini menyebabkan wajib pajak tersebut tidak memiliki motivasi dan kerelaan untuk patuh terhadap peraturan perpajakan.

2. Pada dasarnya Standar Operation Prosedur Direktorat Jenderal Pajak secara umum bukan membina UMKM ini adalah salah satu Inovasi yang dilakkukan untuk meningkatkan kesadaran terhadap kepatuhan Wajib Pajak, karena sifat manusia tidak suka dipaksa dan menginginkan manfaat langsung atau effort/ spending terhadap apa yang dilakukannya. Sikap sadar yang muncul harus dari dalam diri Wajib Pajak sendiri.

3. Persepsi tentang sanksi pajak tidak berpengaruh positif terhadap kepatuhan wajib pajak orang pribadi disebabkan karena persepsi tentang sanksi pajak oleh responden yang merupakan wajib pajak tidak sesuai dengan harapan wajib pajak dan tidak memenuhi unsur keadilan. Wajib pajak tidak memiliki motivasi dan kerelaan untuk patuh terhadap peraturan perpajakan. Kesadaran tidak berpengaruh positif terhadap kepatuhan Wajib Pajak. Ini berarti jika sikap sadar yang muncul dari dalam diri Wajib Pajak itu sendiri maka tindakan patuh terhadap peraturan perpajakan merupakan bentuk pengabdian kepada negara..

\section{Saran}

1. Harus diadakan penelitian ilmiah secara detail dan mendalam mengenai target pencapaian kepatuhan waktu pelaporan SPT bersinergi dengan berbagai komunitas, hasil dari penelitian menunjukkan belum dapat mewakili utuk menjadi target pencapaian.

2. Inovasi yang telah dilakukan oleh KPP Pratama Pondok Aren belum mencapai target yang diinginkan ini dikarenakan kurang maksimal dalam memberikan motivasi atau usaha yang dapat menyebabkan kelompok USP tergerak melakukan sesuatu pencapaian sesuai dengan harapan, setiap anggota USP mempunyai tingkat kemampuan (ability) yang berbeda, dan perlu adanya pendorong (trigger) yang selalu dapat menjaga keutuhan komunitas dan anggota USP.

3. Direktorat Jenderal Pajak harus bersinergi dengan lembaga keuangan untuk mengatasi permodalan yang sering dihadapi oleh peserta pelatihan UMKN untuk meningkatkan omzet dan pengasilannya serta melaksanakan kegiatan pendukung (supporting activities) yaitu kemitraan dengan dunia usaha (industry partnership), aktivitas himbauan (leverage activity), dan kunjungan ke lokasi usaha wajib pajak (spot audit).

4. Kebijakan dan perlakuan perpajakan secara berkesinambungan dilaksanakan dengan mengikutsertakan seluruh lapisan masyarakat misalnya tokoh-tokoh masyarakat, perguruan tinggi, lembaga swadaya masyarakat, asosiasi pengusaha, pedagang maupun profesi agar pemahaman peraturan perpajakan berpengaruh secara positif terhadap kepatuhan wajib pajak orang pribadi.

\section{DAFTAR PUSTAKA}

Agustino, Leo. 2008. Dasar-Dasar Kebijakan Publik. Bandung. Alfabeta

Abdul Rahman. 2010. Panduan Pelaksanaan administrasi Perpajakan untuk Karyawan, Pelaku Bisnis, dan Perusahaan. Bandung: Nuansa

Abuyamin, Oyok. 2010. Perpajakan Pusat Dan Daerah. Bandung: Humaniora. 
Abdul Wahab, Solichin 2008, Analisa Kebijaksanaan Dari Formulasi ke Implementasi Kebijakan Negara. Edisi Kdua. Jakarta: PT. Bumi Aksara

Ahmadi, Nugroho .(2012). "Faktor-Faktor yang MempengaruhiIntellectul capital Disclousure". Accounting Analysis journal .

Andreoni, James; Erard, Brian; dan Feinstein, Jonathan, 2015,2016, Tax Compliance, Journal of Economic Literature. Bappeda Kota Yogyakarta 2015, 2016

Azmi, Anna A. Che and Kamala A.Perumal. 2008. Tax Fairness Dimension in an Asian Context: The Malaysian Perspective. International Review of Business Research Papers, Vol.4, Carolina,

Brotodiharjo, R Santoso. 2013. Pengantar Ilmu Hukum Pajak. Bandung: Rafika Aditama

Carl J Federick Federick, Carl J. 1941. Kutipan Leo Agustino (2008) Public Policy. Chicago: The Univesity of Chicago Press

Charles O. Jones, Aprilia. 2009. Manajemen Sumber Daya Manusia. Jakartami Aksara. Jakarta.

Devano, Sony dan Siti Kurnia Rahayu. 2006, Perpajakan Konsep, Teori dan Isue. Jakarta ; Kencana Prenanda Media Group.

Eddy Suryanto HP. 2013. Account Representative jembatan penghubung bagi kepatuhan wajib pajak. Jurnal Ekonomi dan Kewirausahaan Vol. 13, No. 2.

Ernest R. Alexander. (Published 2013 by Routledge). How Organizations Act Together. New York: Gordon and Breach Sciene Publishers SA

Goerge R.Terry. 2013. Prinsip-prinsip Manajemen, Jakarta. Bumi Aksara

Gulo, Wilmar A., dan Wita J. Ernawati. (2011). Analisis Economic Value Added (EVA) dan Market Value Added (MVA) sebagai Alat Pengukur Kinerja Keuangan PT. SA. Jurnal Manajemen dan Organisasi, Vol. II, No. 2. Agustus

Gunadi. (2005). Fungsi Pemeriksaan Terhadap Peningkatan Kepatuhan Wajib Pajak (Tax Compliance). Jurnal Perpajakan Indonesia

Hadi, Samsul. 2011. Metode Riset Evaluasi. Yogyakarta. Lakbang Grafika.

Hutagaol, John. 2007. Perpajakan Isu-isu Kontemporer, Jakarta: Graha Ilmu.

Haula Rosdiana dan Edi Slamet Irianto, (2012) Pengantar Ilmu Pajak : Kebijakan dan Implementasi Di Indonesia, Jakarta : Rajagrafindo Persada

Humdiana, dan Evi, Indrayani. 2006. Sistem Informasi Manajemen. Yogyakarta: Graha Ilmu. Jogiyanto.

International Accounting Standars Committee (IASC) IASC, AASB, dan APB No. 4

Jogiyanto. 2008. Metodologi Penelitian Sistem Informasi. Yogyakarta. CV Andi Offset

Kantor Pelayanan Pajak Pratama Pondok Aren , 2016 Inovasi UMKM Sahabat Pajak, Tangerang Selatan.

Kotler, Amstrong. 2001. Prinsip-prinsip pemasaran, Edisi keduabelas, Jilid 1. Jakarta: Erlangga

Lubis, S., M. Harry, 2008, Konsumen dan Pasien, Yogyakarta.Liberty

Mankiw, N. Gregory, 2004. Principles of Macroeconomics. Third Edition. Thomson South Western.

Moh. Zain. 2008. Manajemen Perpajakan. Jakarta: Salemba Empat

Nurmantu, Safri 2005. Pengantar Perpajakan. Yayasan Obor Indonesia, Jakarta.

Norman, D. Nowak. 2007. Tax Admnistration Theory and Practice, Jakarta Salemba Empat

Profi Bisnis UMKM Jakarta LPPI 
P.J.A Andriani Dalam Buku Waluyo . 2009. Akuntansi Pajak .Jakarta. Salemba Empat

Pandiangan, Liberti, 2008, Modernisasi dan Reformasi Pelayanan Perpajakan Berdasarkan UndangUndang Terbaru, Jakarta .PT Elex Media Komputindo.

Purwanto, Erwan Agus dan Dyah Ratih Sulistyastuti. 2012. Implementasi Kebijakan Publik: Konsep dan Aplikasinya di Indonesia. Yogyakarta. Gava Media:

Rachmat Soemitro Rochmat Soemitro (2011). Asas dan Dasar Perpajakan . Bandung: Rafika Aditama

Rivai, Veithzal. 2009. Manajemen Sumber Daya Manusia Untuk Perusahaan Dari Teori ke Praktik. Jakarta: Raja Grafindo Persada

Rosdiana, Haula dan Edi Slamet Irianto. 2011. Panduan Lengkap Tata Cara Perpajakan di Indonesia. Jakarta: Visimedia Pustaka.

Scriven, M. (diakses 1 April 2011). Evaluation thesaurus (4th ed.). Newbury Park, CA: Sage. (www.hfrp.org. )

Solihin Abdul Wahab , 2008. Pengantar Analisis Kebijakan Publik. Malang. UPT Penerbitan Universitas Muhammadiyah, Malang.

Siti Kurnia Rahayu, 2010 .Perpajakan Indonesia : Konsep dan Aspek Formal, Yogyakarta : Graha Ilmu.

Sugiyono. 2009. Metode Penelitian Bisnis (Pendekatan Kuantitatif, Kualitatif, dan R\&D). Bandung: Alfabeta

Triandis, H.C. 1980. Attitudes and Attitudes Change. New York: John Willey and Sons Inc.

Wirawan. 2012. Evaluasi:Teori, Model, Standar, Aplikasi, dan Profesi. Depok PT Raja Grafindo Persada

Winarno, Budi; 2014; Kebijakan Publik: Teori, Proses, dan Studi Kasus; Yogyakarta; Center of Academic Publishing Service (CAPS) 